\title{
Nigeria's Petroleum Sector and GDP: The Missing Oil Refining Link
}

\author{
Uyiosa Omoregie \\ Corporate Planning Department, Brass LNG, Lagos, Nigeria \\ Email: uyiosa.omoregie@brasslng.com
}

\begin{abstract}
Nigeria is generally referred to as an 'oil economy' because of the country's large amount of oil reserves. Yet, the petroleum sector in Nigeria currently contributes less than 10 percent of the country's gross domestic product (GDP). In comparison, some Gulf States' petroleum sector GDP contribution is usually more than 30 percent. A fundamental reappraisal of Nigeria's petroleum sector's relationship with the economy is required. This paper posits that the missing link between the petroleum sector and Nigeria's GDP growth is the country's petroleum refining capacity. Capacity utilization of Nigeria's refineries dropped to 14 percent in 2014 against a global average refining capacity utilization of 90 percent. The constraints of crude oil supply to Nigeria's refineries are revealed as well as policy interventions by the Federal Government of Nigeria aimed to increase in-country oil refining capacity. Refining capacity is suggested as an antidote to Nigeria's so-called 'resource curse'.
\end{abstract}

Keywords: Nigeria, petroleum, refining, GDP, economy, resource curse, Niger Delta

\section{Introduction}

This paper analyzes and reveals the true relationship between Nigeria's petroleum sector and the country's economy. The in-country petroleum refining deficit is suggested to be the main gap separating the petroleum sector from a deeper connection with the national economy. Crude oil supply constraints to the refineries are revealed: oil pipeline vandalism, oil theft and the general crisis in the Niger Delta (where most of Nigeria's oil reserves are found). Policy interventions by the Federal Government of Nigeria in recent years aimed to remedy the petroleum refining deficit, are elaborated.

Nigeria has been Africa's largest oil producer for a long time and holds the second largest oil reserves in Africa (after Libya). Nigeria has the 10th largest oil reserves in the world [1]. However, according to the National Bureau of Statistics, Nigeria's petroleum industry contributes less than 10 percent of Nigeria's gross domestic product (GDP): nine percent in 2015 and eight percent in 2016. Is this really an oil-based economy? The importance of the petroleum sector is obvious: it contributes approximately 80 percent of the Federal Government's revenue and 90 percent of Nigeria's export earnings [2]. Nigeria's petroleum sector GDP contribution must be compared with other oil-based economies (countries that actually deserve the description). The petroleum industry contributes more than 50 percent of Kuwait's GDP, this is roughly the same for Qatar; for Saudi Arabia the GDP contribution is 42 percent, it is 30 percent for The United Arab Emirates (UAE) [1].

An often-repeated jingle in policy circles is the need for Nigeria to diversify its economy away from being a mono-product (oil) economy. How will Nigeria diversify its economy from oil when oil contributes less than 10 percent of its GDP? The focus should be to diversify the Federal Government's dependence on petroleum rents. Real diversification from an oil-based economy was successfully implemented by the UAE. The diversification of the UAE economy away from petroleum has been a well-articulated Government policy and priority, since the founding of the UAE in 1971. The UAE was able to survive the oil price crash that began in mid-2014 because the country had by then become a global tourist destination, as well as a major trading and financial center. The non-petroleum sector's percentage contribution to UAE's GDP continues to rise (currently 70 percent up from 60 percent in 2000) [3]. 
The real relationship between the petroleum industry and the Nigerian economy is that the Nigerian State is a rentier State [4]. The Nigerian State derives nearly all of its national revenue from the rents collected by giving external clients access to petroleum resources. So, Nigeria is not really an 'oil economy'. Nigeria is actually a gas province with pockets of oil, and these natural resources bring important rents for the Federal Government. The fall in oil prices in 2014 resulted in a drastic drop in oil revenue for the Federal Government, this reduced Nigeria's external foreign reserves and caused the weakening of the naira against the dollar. The weakening of the Naira contributed to cost-push inflation resulting in recession [5].

Genuine oil economies are economies characterized by low population densities and abundant oil resources. The relationship between oil production and the population density: one barrel of oil produced in Nigeria belongs to 90 Nigerians (compared with one barrel for three Saudis, one barrel for 1.69 Qataris and 1.44 Kuwaitis respectively! [6].

\section{$2 \quad$ Nigeria's Gross Domestic Product (GDP)}

Nigeria's Vision 20:2020 sees Nigeria placed among the top 20 economies in the world with a minimum GDP of $\$ 900$ billion and a per capital income of no less than $\$ 4000$ per annum by the year 2020 [7]. When Vision 20:2020 was documented in 2009, Nigeria was placed 44th in world GDP ranking (two years later Nigeria's GDP was ranked 36th, then after re-basing its GDP moved up to 22nd in 2015.) Nigeria's release of GDP data in 2014 showed GDP of $\$ 454$ billion (2012) and $\$ 510$ billion (2013). The 2014 figures were 'rebased' data using updated and improved methodology.

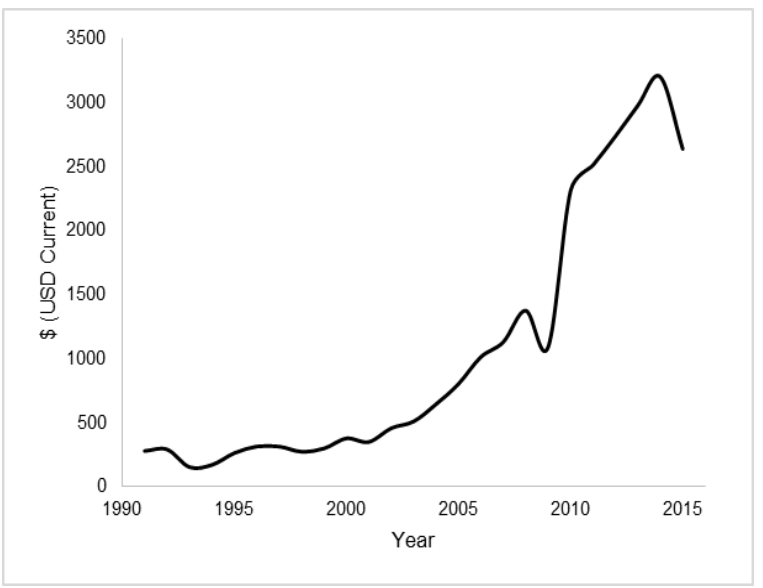

Figure 1. Nigeria's GDP per capita (USD current) [8]

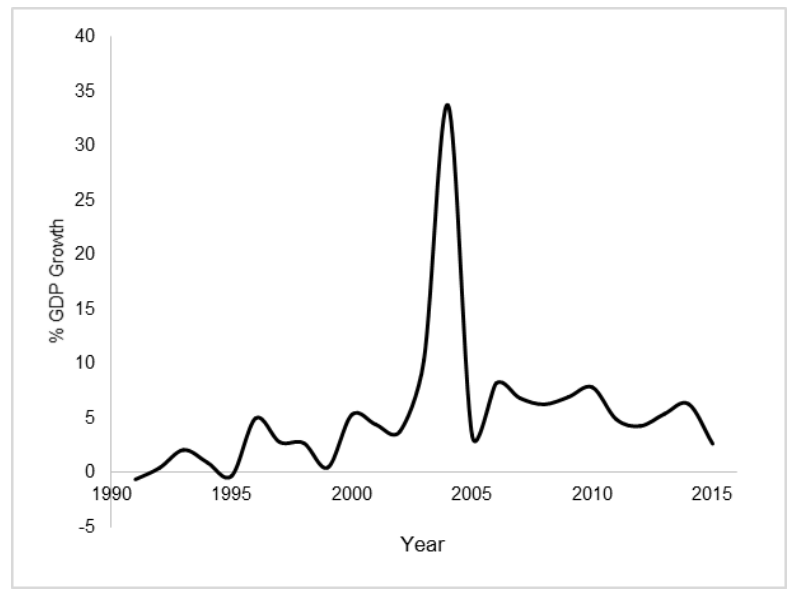

Figure 2. Nigeria's GDP growth (annual percent) [8] 
Nigeria's economy contracted after the oil price plunge and by 2016 the GDP ranking fell to 26th [8]. The petroleum sector in Nigeria must be transformed from being just a source of rents for the Federal Government, to be an important contributor to GDP growth. Other sectors of the economy will also need to increase production capacity. The petroleum industry, however, must provide more consumption opportunities for Nigeria's economy. Only petroleum production in-country for more consumption incountry will be effective. Petroleum products consumption by the Nigerian economy is currently largely the consumption of refined petroleum product imports. Currently, 30 percent of forex demand in Nigeria is for the importation of refined petroleum products [9]. This places enormous pressure on the Naira and harms the economy. A developing country like Nigeria can only sustainably reduce poverty through economic growth. Policymakers all over the world have tried to encourage foreign direct investment (FDI) as they believe it would help increase productivity in-country and usher economic development, mostly through the 'multiplier' effect. However, local economic conditions (absorptive capacities) are factors that limit or enhance the effect of foreign direct investment on economic growth [10].

To grow GDP, more refineries in-country must be built to supply products for domestic consumption. Abundant demand by industries for petroleum products consumption exists: the electricity-power, petrochemicals and fertilizer industries etc. are just some industries waiting to blossom.

\section{Refineries: As link between the Petroleum Sector and GDP}

\subsection{Nigeria's Weak Oil Refining Output}

Nigeria is ranked 72nd in refined petroleum products production (70,000 bbl/day, 2015 estimate) and $82 \mathrm{nd}$ in refined petroleum products exports (11,000 bbl/day, 2014 estimate) [11].

Table 1. Nigeria's refined petroleum products production benchmarked against some Gulf countries [11]

\begin{tabular}{lll}
\hline Country & Refined Petroleum Production & Ranking \\
\hline Saudi Arabia & $2,220,000 \mathrm{bbl} /$ day & 9 \\
Kuwait & $920,000 \mathrm{bbl} /$ day & 23 \\
U.A.E & $480,000 \mathrm{bbl}$ day & 33 \\
Qatar & $279,000 \mathrm{bbl} /$ day & 44 \\
Nigeria & $70,000 \mathrm{bbl} /$ day & 72 \\
\hline
\end{tabular}

Table 2. Nigeria's refined petroleum products exports benchmarked against some Gulf countries [11]

\begin{tabular}{lll}
\hline Country & Refined Petroleum Product Exports & Ranking \\
\hline Saudi Arabia & $1,600,000 \mathrm{bbl} /$ day & 6 \\
Qatar & $500,000 \mathrm{bbl} /$ day & 15 \\
Kuwait & $400,000 \mathrm{bbl} /$ day & 20 \\
U.A.E. & $335,000 \mathrm{bbl} /$ day & 26 \\
Nigeria & $11,000 \mathrm{bbl} /$ day & 82 \\
\hline
\end{tabular}

\subsection{Nigerian Government's Policy Intervention}

Nigeria's Federal Ministry of Budget and National Planning's Economic Recovery and Growth Plan [12] (ERGP 2017-2020) was released March 2017. The ERGP stressed the "urgent need as a nation to drive a structural economic transformation with an emphasis on improving both public and private sector efficiency." The ERGP's aim is to grow Nigeria's GDP by 4.62 percent on average over the plan period (2017-2020). The ERGP was released when Nigeria was in the midst of a recession (GDP contracted 1.54 percent in 2016). The recession was ultimately triggered by the petroleum industry: the drastic crash of the oil price in mid-2014 reduced the Federal Government's oil revenue which impacted the foreign reserves. The crash of the Naira followed, resulting in cost-push inflation [5]. As the Federal 
Government of Nigeria depends on the petroleum industry for about 80 percent of its revenue [2], the oil price crash was a severe blow to the Federal Government's finances.

The ERGP desires a ramp up of oil production by 2020 to 2.5 million barrels per day, and the privatization of selected public enterprises and assets, revamping of local refineries to reduce refined petroleum products imports by a margin of 60 percent by 2018. It is important to emphasize again that part of the pressure that led to the devaluation of the Naira (foreign exchange pressure) was increased demand for Dollars. (30 percent of the demand for foreign exchange is to enable the importation of refined petroleum products) [9].

The ERGP segments the petroleum sector in Nigeria into two sub-sectors:

(a) The upstream production of crude oil and natural gas (mostly for export)

(b) The downstream activities of petroleum refining, petrochemicals production etc.

According to the ERGP, the upstream sub-sector has been a pillar to the Federal Government's finances for decades. Although it contributed only about nine percent of GDP in 2015, it accounted for more than 90 percent of Nigeria's export earnings and about 62 percent of the Federal and State Governments revenue. In contrast, the downstream sub-sector accounted for just 0.3 percent of GDP in 2015.

To remedy this deficit, policy interventions such as the Federal Ministry of Petroleum Resources '7 Big Wins' Initiative (2015) [13] and the National Petroleum Policy (2017) [14], have laid emphasis on the value that a reinvigorated refining industry can add to Nigeria's economy.

Nigeria's Minister of State for Petroleum resources unveiled the '7 Big Wins' initiative aimed at growing the petroleum industry, in a transparent manner, more efficiently, creating a more stable investment climate. He acknowledged that the Initiative requires new partnerships among key stakeholders, new technology, new ideas and innovative thinking. Regarding 'refining and local production capacity', the 7 Big Wins Initiative has this strategy: "Completing the rehabilitation and enhancing utilization of our local refineries in addition to setting up of co-located refineries and modular refineries to guarantee effective supply and distribution of products across the country and African subregion is a key focus area of the current administration." [13]

According to the Initiative, this strategy is aimed at helping Nigeria transit "from being a massive importer of petroleum products to a net exporter of petroleum products and value-added petrochemicals to diversify our export base and enhance import substitution, GDP growth and employment generation."

Nigeria's National Petroleum Policy (NPP) was approved by the Federal Executive Council (FEC) July 2017. The NPP's vision is for Nigeria to be a nation where "hydrocarbons are used as fuel for national economic growth and not simply as a source of income." The NPP came into being because previous Federal Government policies over the years were not designed for economic development and instead encouraged a rent-seeking approach. Nigeria ended up as the only member of the Organization of Petroleum Exporting Countries (OPEC) without effective oil refining capacity. One of the objectives of the NPP is to create value for the Nigerian economy by processing oil into important products for other industries. The future of the oil sector in Nigeria lies in refining and petrochemical industries. The NPP states that capacity utilization of Nigeria's refineries dropped to 14 percent in 2014 against a global average of capacity utilization of 90 percent. The NPP states (very early on) that "a strong commercially viable and significant refining sector is an essential part of the National Petroleum Policy."

As part of the NPP, a new oil refining model is presented: refineries are expected to sell their end products directly to different buyers (multiple off-takers). Government-owned (or partially-owned) refineries will have new independence, as the refineries will be allowed to source crude oil independently (not restricted to the National Oil Company deliveries only). The NPP envisages different strategies to infuse private sector expertise (commercial/technical/finance) into the government-owned refineries.

\subsection{Refining Oil as Antidote to the 'Resource Curse'?}

According to the 'resource curse' theory, mineral-based economic development has mostly failed in latercomer economies. The theory posits a paradox: an abundance of natural resource mostly results in negative socioeconomic outcomes in developing countries. It appears that an abundance of natural 
resources should cause high economic growth but the opposite has been the experience: low economic growth with civil conflict and proliferation of weak institutions. It has been suggested that oil-abundant countries experience low economic growth due to the enclave nature of the oil industry. The industry is insular and minor developments occur around the oil industry with a neglect of the manufacturing sector. Although oil production is very capital-intensive and has few automatic linkages to other sectors of the economy, the absence of refining capacity in poor oil-producing countries may be more to do with political considerations. A deliberate policy for in-country refining capability and value creation linking the upstream and downstream sub-sectors of the economy, will create additional forward and backward linkages to other sectors of the economy.

Baur [15] showed that a country like Nigeria can mitigate the resource curse by increasing its refining capacity, as this will improve economic and institutional outcomes of an oil-producing country like Nigeria. Increased midstream and downstream capacity should increase the availability of petroleum products, its consumption, enhance linkages to other sectors and ultimately diversify the economy. Also, Baur argues that "coupling national strategies for developing downstream capacities with supplying internal demand and energy self-sufficiency may reduce the 'rentier effects' associated with serving a most external market." Baur's analysis appears to be the first attempt by a researcher to estimate the impact of refining capacities (quantitatively) on economic growth and institutional quality. The empirical results obtained by Baur show that increased economic growth and a reduction in petroleum dependence is statistically significant and positively correlated with an expansion of refining capacity in a country.

\section{The Niger Delta Security Issue and Oil Refining}

\subsection{Oil Theft}

Crude oil stolen from Nigeria is 'on an industrial scale' and some of the stolen oil is exported to buyers outside Nigeria. Proceeds from stolen crude oil are laundered through sophisticated international financial networks [16]. Due to the opaque nature of Nigeria's oil industry, the official crude oil sales process, the revenues accruing from the sales - the entire hydrocarbon flows - have hidden elements that make the oil revenue leakages easy to conceal. In the Niger Delta, oil is stolen directly at oil export terminals. By sabotage of oil infrastructure, especially pipelines, oil is stolen and transported by barges or boats to be exported or refined locally. These illegal operations involve a network of security people, local and foreign actors. Oil theft in the Niger Delta is a complicated issue, a cause and a symptom of violent conflict: theft occurs out of violent conflict (symptom) but oil theft also occurs in the absence of conflict, but then leads to conflict (cause). It was estimated that in the first quarter of 2013 alone, approximately 100,000 barrels per day (about five percent of total output) was stolen in the Niger Delta [16]. Some analysts have estimated the amount of stolen oil to be as much as 150,000 barrels per day [17]. The Federal Government of Nigeria's Petroleum Revenue and Special Task Force (PRSTF) report in 2012 [18] states that:

Hydrocarbon theft was found by the Task Force as being a major and chronic source of revenue loss to Nigeria. Theft of crude oil and refined petroleum products may be reaching emergency levels in Nigeria. The Task Force

observed various estimates by International Oil Companies and Government officials of the scale and volume of crude theft which ranged from 6 to 30 percent of production...it could actually be as high as 250,000 barrels per day closer to 10 percent of daily production

The Nigeria Natural Resource Charter (NNRC) 2018 "Oil Theft in Nigeria Report" revealed that Nigeria lost approximately $\$ 10$ billion to oil theft in 2016 [19]. Oil theft was mainly through sabotage and pipeline vandalism. To put the $\$ 10$ billion figure in perspective, it was noted that the Federal Government of Nigeria's combined allocations for health and education (approximately $\$ 0.8$ billion) is less than nine percent of the value of oil stolen. The NNRC report noted that the force majeure declared at the Forcados terminal was the primary reason for the losses as well as pipeline sabotage and theft. Further, systemic corruption, unemployment, poverty, and poor governance, were revealed by the NNRC report as reasons behind oil theft over the years, with the Federal Government's almost neglect of the Niger Delta region central to the issue. 


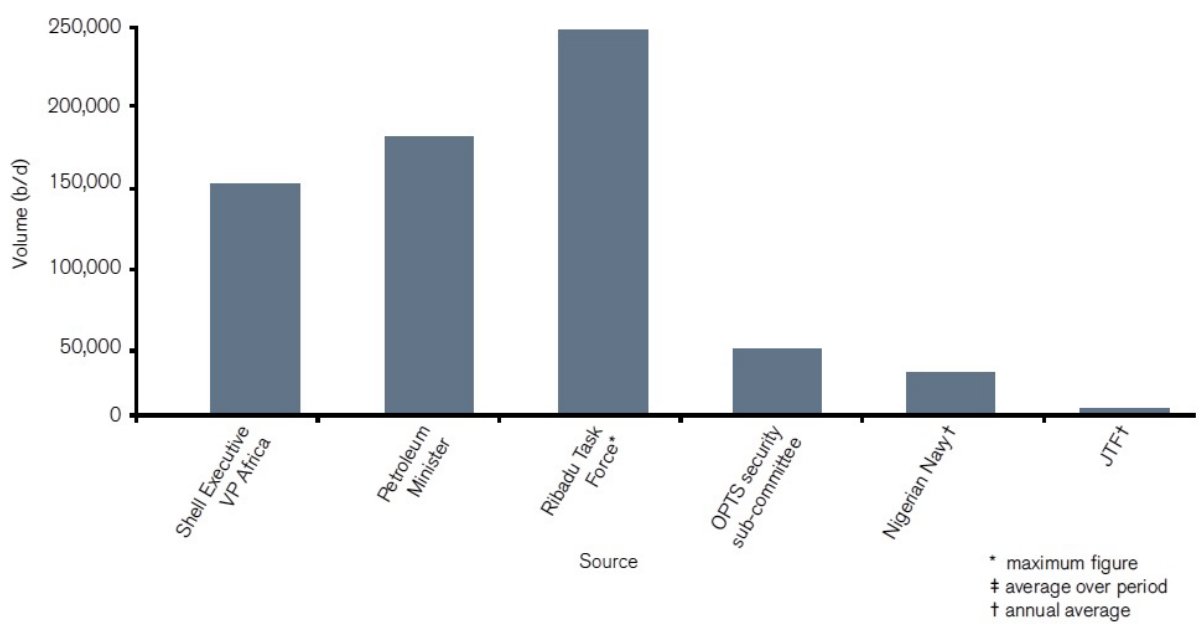

Figure 3. Nigerian oil theft: publicly quoted estimates [16]

\section{$4.2 \quad$ Illegal Refining}

One estimate is that approximately 25 percent of oil stolen in the Niger Delta is consumed or refined in the Niger Delta [18]. This 25 percent is a $\$ 300$ million per annum industry. This underground economy from illegal refining provides employment for people in the Niger Delta communities while supplying the communities with refined petroleum products. Between 2005 - 2009, militant camps in the Niger Delta perfected and modernized a basic oil refining technique pioneered during the Biafra civil war.

Table 3. Rough estimates of the scale of illegal refining activities the Niger Delta [17]

\begin{tabular}{ll}
\hline Estimated volume crude oil stolen daily & 150,000 international barrels \\
Proportion of stolen crude sold locally and internationally & $25: 75$ \\
Volume of stolen crude processed locally each day & 37,500 international barrels \\
Total number of refining camps & 500 \\
Average daily tap output & 1800 Niger Delta Drums* \\
Average daily refined products output of medium-size camp & 30 Niger Delta Drums* of product \\
\hline
\end{tabular}

Note: ${ }^{*}$ The Niger Delta Drum holds 200 liters of crude as opposed to the international barrels that hold 160 liters of crude.

\subsection{Supply Constraints to Legal Refineries}

The Federal Government-owned refineries have had unscheduled downtime forced upon them by supply pipeline vandalism. In 2011, The Nigerian National Petroleum Corporation (NNPC) revealed an increase of pipeline vandalism by 224 percent over what occurred in 2010 [20] (there were 2,768 cases of pipeline vandalism in 2011). According to NNPC pipeline vandalism caused about 700,000 barrels per day of crude oil to be deferred in 2016. This sabotage caused a 40 percent reduction in Nigeria's crude oil production. Out of the 2.2 million per day production target for 2016, only 1.3 million barrels per day was achieved, as production was hampered by pipeline vandalism [21].

In most discussions about the government-owned refineries, the emphasis has been mostly on the supply-side (supplies from the refineries): the refineries do not work enough to supply products to the market. During an interview [22], the Chief Operating Officer of Refineries at NNPC, when asked about the status of the three refineries gave a number, which emphasized the demand-side of the refineries: $162,475,000$ barrels of crude oil per year (445,000 x 365 days) refining capacity of the refineries. In 2015, a mere eight million barrels were delivered to the refineries (approximately five percent capacity utilization). The new management of NNPC made efforts to triple crude oil delivery to 24 million barrels in 2016 . 
Engagement with oil community stakeholders by the Federal Government and NNPC in 2017 resulted in 12 percent reduction in downstream pipeline vandalism [23]. The Managing Director of the Port Harcourt Refining company, when he received members of a committee of the National Security Adviser, stated that the Port Harcourt Refinery can now accept and process crude oil recovered or seized from 'vandals' [24].

\section{Conclusion}

The petroleum sector in Nigeria has the potential to contribute much more to Nigeria's GDP than it current does. The Federal Government of Nigeria must not be complacent, satisfied that the sector funds nearly all of the Federal Government's revenue (through royalty payments and taxes). Recent policy interventions by the Federal Government must be commended. The challenge and true test will be in the implementation of the policies. With increased in-country petroleum refining capacity, the petroleum sector will be more connected to the wider economy, resulting in greater contribution to the country's GDP. This is probably the only route out of the so-called 'resource curse' that Nigeria seems to have suffered for decades.

\section{References}

1. Central Intelligence Agency,

Available: https://www.cia.gov/library/publications/the-world-factbook/rankorder/2244rank.html

2. National Bureau of Statistics, Available: https://www.nigerianstat.gov.ng

3. Trends Research \& Advisor, Available: http://trendsinstitution.org/uae-economic-diversification-record/

4. Z. Usman (2016), "The successes and failures of economic reform in Nigeria's post-military political settlement," GEG Working Paper 115, University of Oxford, Available: http://www.geg.ox.ac.uk/successes-and-failureseconomic-reform-nigeriapercentE2percent80percent99s-post-military-political-settlement

5. A. Teriba (2018), "Harmonization of fiscal and monetary policies in Nigeria," Available: https://papers.ssrn.com/sol3/papers.cfm?abstract_id=3163481

6. PM News, Available: https://www.pmnewsnigeria.com/2017/11/05/change-nigeria-not-oil-economy/

7. National Planning Commission, Available: http://www.nationalplanningcycles.org/D5EB7E39-063B-4E358E966A449A83B39D/FinalDownload/DownloadId-EB7E2ACCDA4CC35422A0BE3BE0923675/D5EB7E39-063B4E35-8E96-6A449A83B39D/sites/default/files/planning_cycle_repository/nigeria/nigeria-vision-20-20-20.pdf

8. The World Bank, Available: https://data.worldbank.org/data-catalog/GDP-ranking-table

9. Punch, Available: http://punchng.com/30-per-cent-forex-spent-fuel-imports-adeosun/

10. U. Omoregie (2015) "A developing country's absorptive capacity: the link between FDI and economic growth in Nigeria." Open Access Library Journal, 2, e2137. doi: http://dx.doi.org/10.4236/oalib.1102137.

11.Central Intelligence Agency,

Available: https://www.cia.gov/library/publications/the-world factbook/geos/ni.html

12. Federal Republic of Nigeria Ministry of Budget and National Planning,

Available, https://yourbudgit.com/wp-content/uploads/2017/03/Economic-Recovery-Growth-Plan-2017-2020.pdf

13. Federal Ministry of Petroleum Resources, Available: http://petroleumresources.gov.ng/7-big-wins/

14. Federal Ministry of Petroleum Resources, Available: http://www.7bigwins.com/wpcontent/uploads/2017/07/ National-Petroleum-Policy-Approved-by-FEC-in-July-2017.pdf

15. S. Baur (2014) "Refining oil -a way out of the recourse curse?" London School of Economics Working Paper Series No.14-158, Available: https://www.files.ethz.ch/isn/182758/WP158.pdf

16. Chatham House, Available: https://www.chathamhouse.org/publications/papers/view/194254

17. Stakeholder Democracy Network, Available: https://www.stakeholderdemocracy.org/sdn-report-communitiesnot-criminals-illegal-oil-refining-in-the-niger-delta/

18. Business News, Available: http://businessnews.com.ng/wp-content/uploads/2012/10/Report_of_the_Ribadu_ led_Petroleum-Revenue-Special-Task-Force-2012.pdf

19. Punch, Available: https://punchng.com/n3-8tn-lost-to-oil-theft-in-2016-nnrc/

20. Nigerian National Petroleum Corporation, Available: 
http://www.nnpcgroup.com/PublicRelations/OilandGasStatistics/AnnualStatisticsBulletin.aspx

21. Premium Times, Available: https://www.premiumtimesng.com/news/headlines/243204-pipeline-vandalismreduced-nigerias-oil-production-40-nnpc.html

22. M. Mukwuzi and C. Umeh (2017), "Cracking the refinery challenge," NNPC Magazine, Q4, pp.16-30

23. Nigerian National Petroleum Corporation, Available:

http://www.nnpcgroup.com/PublicRelations/NNPCinthenews/tabid/92/articleType/ArticleView/articleId/807/

Oil-Pipeline-Vandalism-Drops-by-12-Per-Cent.aspx

24. I. Okpanni (2018), "PHRC will process seized, recovered crude if...MD," PHRC News Q1, pp.9-10 